\title{
Environmental chemistry course assisted problem-based learning in developing students' higher-order thinking skills and characters.
}

\author{
Wildan $^{[a]}$, Supriadi ${ }^{[a] \star}$, Dwi Laksmiwati ${ }^{[a]}$, and Rizki Nur Analita ${ }^{[b]}$ \\ [a] Chemistry Education Study Program \\ Faculty of Teacher Training and Education, University of Mataram \\ Jalan Majapahit No. 62 Mataram, Indonesia \\ E-mail: Supriadi fkip@unram.ac.id \\ [b] Chemistry Education Study Program \\ Faculty of Teacher Training and Education, University of Lambung Mangkurat
}

\section{DOI: $\underline{10.29303 / a c a . v 4 i 1.54}$}

\section{Article info:}

Received 23/10/2020

Revised 29/01/2021

Accepted 29/09/2021

Available online $26 / 10 / 2021$

Abstract. Character development and higher-order thinking abilities are crucial in environmental chemistry courses because they can motivate students to care about the environment. Environmental chemistry courses can benefit from a problembased learning approach. Students learn to think critically and analytically, as well as locate and use relevant learning resources, through problem-based learning. This was a quasi-experimental study that used a pre-test post-test design. The goal of this study was to describe how problem-based learning was implemented in environmental chemistry classes and how it influenced the development of higherorder thinking abilities and student personalities. Data was gathered through an essay test that required higher-order thinking skills, and students' personalities were determined through an inventory. ANOVA statistics were used to evaluate the data. The stages of concept presentation, presentation of factual problems in various forms, group discussions, and class discussions were used to implement problem-based learning in the Environmental Chemistry course; (2) problem-based learning can significantly improve students' higher-order thinking skills and characters; and (3) high-order thinking skills contribute significantly to character development.

Keywords: Problem-based learning, Higher-order thinking skills, Characters

Citation: Wildan, Dwi Laksmiwati, Supriadi, and Rizki Nur Analita. (2021). Environmental Chemistry Course Through Problem-based Learning to Develop Students' Higher-order Thinking Skills and Characters. Acta Chimica Asiana, 4(x), 141-146. DOI: 10.29303/aca.v4i1.54

\section{INTRODUCTION}

Science, technology, and pedagogy, especially in the future, develop exponentially, demanding the world of education return to its essence, namely education is a process of civilizing and empowering students continuously through Observation-based learning and Collaborative learning-based to emphasize thinking skills at the high impact level on character development [1].

Problem-solving talents, creative thinking abilities, critical thinking abilities, argumentation abilities, and decision-making abilities are all examples of higher-order thinking capabilities. Comprehension, problem-solving, critical thinking, and providing practical arguments are examples of higher-order thinking skills (practical reasoning). The process of developing an internal image of freshly entered data is known as understanding [2]. Understanding is related to the interpretation of the meaning or meaning of events, information, and phenomena and befits the influence of a stronger direction of thought and action with regard to information that just enters. Higher-order thinking skills are cognitive-level thinking processes that are developed from various concepts, cognitive methods, and learning taxonomies such as problemsolving methods. Based on these definitions, higherlevel thinking skills include learning skills and learning strategies that use expressing reasons, thinking creatively and innovatively, making decisions, and solving problems.

According to Krathwohl [3,] higher-order thinking skills include (1) analyzing (C4), which is the ability to separate concepts into several components and connect them to gain an understanding of the concept as a whole, (2) evaluating (C5), which is the ability to determine the degree of something based on norms, specific criteria, or benchmarks, and (3) 
creating (C6), which is the ability to combine elements into something new, complete, and compliant.

Critical thinking is the activity of analyzing arguments and bringing insight to each meaning and interpretation to develop a cohesive and logical pattern of reasoning. Critical thinking is not just looking for answers, but the most important thing is to ask the truth of the answers, facts, or information available. Based on some of the concepts above, in this study, higher-order thinking skills are higher-level thinking skills that require more complex thought processes that include critical thinking, logical reasoning, systematic thinking, analytical thinking, synthesis thinking, and evaluative, so that they can be used to make decisions in solve problems and form positive attitudes and behaviors (good character) [4].

Character is a quality that each individual have in order to live and work together in the context of family, community, nation, and state. Individuals with good character are capable of making judgments and are willing to accept responsibility for the consequences of their decisions [5]. Suharjana [6] defines character as a manner of thinking, acting, and behaving that distinguishes a person and develops a habit that is shown in social situations. Based on these definitions of character, it can be concluded that the characters contain three keywords, namely how to think, behave, and act. Referring to this in the context of this paper, what is meant by character is a way of thinking, behaving, and behaving that characterizes a person's habits in social life. This character will be formed through the way of thinking someone who will lead someone in taking a stand, and the attitude will motivate and encourage an action done consistently and continuously so that it becomes a habit.

Character building can be done through capitalizing on ways of thinking and behaving, both in the learning and in the assessment processes. Good ways of thinking can be formed through the development of high-level thinking skills that can lead to the formation of attitudes and manifest in the form of good behavior. Hill [7] states that character education determines ways of thinking and behavior. Good character can be an incentive to do good, approve and do good, or have noble character.

LeBlanc and Gallavan [8] add character to the affective domain. The opinion of Hill, LeBlanc, and Gallavan was extended by Zuchdi [9] that character education is the attitude and behavior that should be carried out towards God Almighty, society, country, nature, and self. Character involves elements of "knowledge, feeling, loving, and acting." Anderson [10] mentions that character is part of the effective sphere consisting of (1) attitudes, (2) interests, (3) values, and (4) self-concepts whose data are collected through observation and self-report methods, assuming that those who know the situation someones affective is himself.

The problem-based learning model starts from presenting problems from the real world as a stimulus that requires students to learn to use a variety of knowledge and requires students to be collaborative, communicative, and cooperative [11]. Rianto [12] states that problem-based learning is a learning model that exposes students to the challenge of "learning to learn". Students actively work together in groups to find solutions to real-world problems. The closer the problem presented to the real world, the better problem-based learning [13].

Widyatiningtyas et al. report that problemsolving instruction is better than expository methods. It is also in terms of student learning activities [14]. The reasoning abilities of students who are given learning with problem-based instruction are better than conventional learning.

Environmental chemistry courses are suitable to be taught through a problem-based approach because the objectives of this course, in addition to mastering the concepts of environmental chemistry, also the development of attitudes and behaviors towards various things related to the environment, such as the causes of environmental problems, efforts that can be made to inhibit and fix environmental problems both as individuals and as members of the community [15].

The syntax of problem-based learning is (1) Students' orientation to problems; (2) Organizing students; (3) Guiding individual and group investigations; (4) Develop and present results; (5) Analyzing and evaluating the process and results of problem-solving (Arends, 2010). Problem Based Learning prepares students to think critically and analytically and to find and use appropriate learning resources [16].

\section{MATERIALS AND METHODS}

This is a pre-experimental study with a pre-test posttest design, conducted with a class of 31 students in semester 3 (three) of 2019/2020 who are enrolled in Environmental Chemistry courses.

Table 1. Distribution of study samples by age and gender

\begin{tabular}{ll}
\hline Category & Total \\
\hline Ages 19-20 & 11 students \\
Ages 21-22 & 20 students \\
Men & 5 students \\
Women & 26 students \\
\hline
\end{tabular}

There are 7 main subjects being studied in environmental chemistry courses, namely (1) Ecosystems and natural resources, (2) air pollution, (3) water pollution, (4) soil pollution, (5) waste treatment (6) environmental issues, and (7) toxicological chemistry. Lectures were held in 16 meetings (one semester). 
The lecture was divided into two stages. In the first stage (for 7 meetings), the lectures use a conventional approach with lecture method, questions and answers assisted by powerpoint and teaching materials. In the second stage (for 9 meetings), the lectures use a problem-based learning model. I am learning syntax according to Arends [17] as in table 2 below.

Table 2. Syntax of problem-based learning models

\begin{tabular}{ll}
\hline Stages & Activities \\
\hline $\begin{array}{l}\text { Student orientation to } \\
\text { problems }\end{array}$ & $\begin{array}{l}\text { The teacher communicated the learning } \\
\text { objectives, described the logistics (items } \\
\text { and equipment) required for problem- } \\
\text { solving, and encouraged students to } \\
\text { participate in problem-solving activities.. } \\
\text { The teacher assisted pupils in defining and } \\
\text { organizing their learning such that it was } \\
\text { applicable to problem-solving. }\end{array}$ \\
Organizing students & $\begin{array}{l}\text { The teacher encouraged students to find } \\
\text { appropriate information, conduct } \\
\text { experiments, and look for explanations and } \\
\text { problem-solving. }\end{array}$ \\
investigation & $\begin{array}{l}\text { The teacher aided pupils in developing } \\
\text { plans and achieving results that were } \\
\text { appropriate for the assignment. }\end{array}$ \\
Present the results & The teacher assisted students in reflecting \\
Analyze and evaluate \\
process and the findings of their research as well as \\
on the learning processes that had taken \\
results of problem- \\
solving
\end{tabular}

Syntax was carried out on each subject. The problems given were real problems that occur around students, such as waste problems in West Nusa Tenggara, livestock industry problems that cause global warming, pollution due to microplastics, industrial hazardous waste disposal problems, and forest fires. At each meeting, the three researchers came to observe the ongoing learning activities.

Data collection on learning outcomes of highlevel thinking skills and student character was done at the last meeting. The instrument used to measure higher-order thinking skills was in the form of a description test, while the students' character was measured using an inventory. The test consists of 5 (five) breakdown questions with stimulus in the form of current environmental facts. Students were asked to answer these questions with the concepts, principles, rules/environmental as they have learned. The inventory used to measure student characters consists of 40 statements compiled based on 4 (four) character indicators, namely (1) attitude consisting of 9 items, (2) Interest consists of 10 items, (3) Value consists of 9 items, and (4) Self-concept consists of 12 points. The forty points of the statement were accompanied by seven alternative answers, namely strongly disagree, disagree, somewhat disagree, quite agree, agree, somewhat agree, and strongly agree.

All evaluation instruments were tested for validation using Pearson's Moment Product correlation while reliability testing using the Spearman-Brown formula. All test items were declared valid with a correlation index ranging from 0.43 to 0.73 with a reliability coefficient of 0.78 .

Data analysis was done with the ANOVA test on the scores of high-order thinking skills and character before learning (pre-test) and after learning (post-test) using problem-based learning. ANOVA test was done through the IBM SPSS statistic 22. application.

\section{RESULTS AND DISCUSSION}

\section{a. Description of Problem Based Learning}

The study of environmental chemistry in this study was carried out in 2 (two) stages. The first stage is to use 7 (seven) meetings with the main goal so that students better understand the basic concepts in environmental chemistry courses as a pre-requisite to attend lectures with a problem-based approach. At this stage, an outline of all materials on environmental chemistry was discussed by distributing the textbooks that have been prepared by previous researchers with a conventional approach using lecture, question and answer, discussion, and concludes with data collection on student characters with an inventory.

In the second stage, students were divided into 6 discussion groups, and 6 (six) environmental problems were distributed, which were presented in the form of videos, photos, news/writings, policy policies, and data relating to environmental problems accompanied by problems or assignments to be discussed either in class that is continued outside the classroom according to the group's agreement. Group discussions were held for 3 (three) meetings, and each group must report the results of group discussions in the form of papers and power points as presentation material in plenary discussions.

During the group discussion, the lecturer team consisting of 2 (people) actively went around and sat down to listen and watch the discussion. Based on the observations of the group discussion nets the impressions obtained during group discussions, it shows that most students were very active in asking questions, answering friends' questions, and arguing in their groups. During the group discussion, some of the problems were not answered, so it continued outside the classroom. When gathering group assignments, 4 (four) groups were able to submit paper assignments and power points on time. Others submit assignments at the next meeting. Then there was a class discussion for 3 (three) meetings. At each meeting, 2 (two) groups present their respective group assignments obtained through sweepstakes at the previous meeting. Other groups provided input or asked questions.

Based on the observations during class discussions, all groups were very active in responding 
and defending their opinions based on the references they used, such as books, journals, and papers that they obtained from various sources. After class discussion, the research team provided input on the course of the discussion. At the last meeting, the final exam was conducted with a description form that was similar to the group discussion material and character measurements using an inventory sent via Google forms on each cell.

\section{b. High-Order Thinking Skills Learning Outcomes}

Data of High Order Thinking Skills (HOTS) of students were obtained through tests consisting of 5 (five) items of case analysis form. Each item was given a stimulus in the form of pictures/photos, tables, articles, and policies related to environmental problems. In each question, students were assigned to analyze the causes, processes, impacts, and efforts to slow down and/or overcome environmental problems.

From the ANOVA test results, the value of $F=$ 107.245 (Sig.0.000) was obtained. Based on these results, there are differences in the score of pre-test and post-test learning outcomes. The significant difference in learning outcomes was not due to chance but because of the problem-based learning model. The difference in learning outcomes occurred because before problem-based learning was carried out, the students have gained knowledge of the concepts, principles, rules, and basic principles of environmental chemistry from teaching materials that have been prepared, other sources, and researchers' explanations. This causes when problem-based learning, students already have the initial ability to attend group discussions and class discussions as a means of gaining knowledge and higher-order thinking skills.

From the results of observations during learning, there is a difference in the increase of student activity in group discussions and class discussions. The increased activity is partly because the problems that were used as themes/topics of discussion were the real problems in daily life, so they can be experienced by students. not only that, they were also actively seeking learning resources because the activeness in the discussion became a material consideration in determining the final value.

This is in line with Phee's opinion [18], who claims that giving pupils a problem to solve and the process of solving it can help them retain and understand the content more easily. The same idea was said by Akcay [19], who stated that problem-based learning can build learning environments that are centered on student engagement, allowing students to construct knowledge and integrate lessons acquired in school into their daily lives. According to Belt [20], problem-based learning can boost student motivation. Students can learn to be more self-sufficient, dependable problem solvers, and to develop professional abilities.

According to Hmelo-Silver \& Barrows [21], the challenges presented in PBL learning do not have a single solution, requiring students to engage in inquiry with several solution options. Students' participation in PBL can aid in the development of critical thinking abilities by including them completely in the learning process through problem-solving exercises. Students must be able to develop critical thinking abilities in order to solve the challenges stated and form conclusions based on their comprehension in this problem-solving assignment.

Chen [11] states that problem-based learning is an effective approach to help students grow to learn and integrate knowledge and concepts previously learned in the classroom. In activities in problem-based learning, students gain creative thinking skills and professional skills. The above opinion is reinforced by the opinion of Echavarria [22], that problem-based learning is a pedagogical strategy that is centered on students by examining problems in daily life and working in teams or groups, thereby being able to train students to be responsible for their own learning and change the role of educators to become facilitators. This is also the same as the opinion of Machingambi [23] that learning motivation is an internal process that exists within a person who gives enthusiasm or enthusiasm in learning, containing efforts to achieve learning goals, where there is an understanding and development of learning.

\section{c. Students Character}

Information about the character of students before and after problem-based learning (PBL) is obtained through an inventory consisting of 40 items with alternative answers from 1-7, so the range of theoretical scores ranges from $40-280$, with a median of 160 .

From the ANOVA test results, the $F$ value is 130,619 (sig. 0,000). These results prove that the difference in the character scores of the pre-test and post-test did not happen by accident, but it occurred because of the influence of an environment-based learning model. Based on these results, it is concluded that problembased learning in the Environmental Chemistry course can develop students' character in a more positive direction. The character development occurs in all of the components making up the character, namely the attitude component $(F=23,666)$, interests $(F=$ $15,618)$, values $(F=15,753)$ and self-concept $(F=$ $20,828)$. These results indicate that the components of the character consisting of attitudes, interests, values, and self-concept are valid as components of character. 
According to Torrance [24], a learning model that is oriented to problem-solving as in problem-based learning is effective learning to improve the character of students. The same thing was stated by Nugroho [25], who states that character formation occurs with several stages to change personal character, which starts from dissatisfaction, followed by having a logical and rational vision, being brave to take risks, being responsible until reaching a consistent stage. Problembased learning can make these stages happen.

Based on the results of post-test data analysis, it was found that the results of high-level learning and student characters obtained a correlation coefficient (ryx) of 0.729 with a coefficient of determination (ryx) 2 of 0.532 through the regression equation $Y=-15.049+$ 2.707X. Thus 53.2 percent of the students' character after attending environmental chemistry learning with a problem-based approach was contributed by high-level learning outcomes. These results are in line with the results of Martawijaya's [26] study, which reported that there was a significant relationship between higherorder thinking skills and student character. The relationship between HOTS and student character is caused by one's ability to see, observe, predict, think, guess, consider, assess, and solve problems that will affect moral development in him. The better one's thinking ability, the more likely it is to have good moral development, and vice versa.

\section{CONCLUSION}

According to the data analysis, the implementation of problem-based learning in the Environmental Chemistry course with the stages of concept presentation, problem presentation, group discussion, and class discussion can go well and increase student activities in learning. Problem-based learning in Environmental Chemistry courses can help students develop their character while also improving their higher-order thinking skills. Character development benefits greatly from higher-order thinking abilities.

\section{ACKNOWLEDGEMENTS}

The authors would like to thank the support of the University of Mataram for funding this research.

\section{REFERENCES}

[1] Pepper, C. (2009). Problem Based Learning in Science. Issues in Educational Research, 9 (2): 128-141.
[2] Lewis, A., \& Smith, D. (1993). Defining higher order thinking. Theory into practice, 32(3), 131137.

[3] Krathwohl, D. R. (2002). A revision of Bloom's taxonomy: An overview. Theory into practice, 41(4), 212-218.

[4] Condon, W., \& Kelly-Riley, D. (2004). Assessing and teaching what we value: The relationship between college-level writing and critical thinking abilities. Assessing Writing, 9(1), 56-75.

[5] Suyanto. (2009). Urgensi Pendidikan Karakter. Diakses pada tanggal 10 April 2011 dari http://www.mandikdasmen.depdiknas.go.id/we/p ages/urg ensi.html.

[6] Suharjana. (2011). Model Pengembangan Karakter melalui Pendidikan Jasmani dan Olahraga. Yogyakarta: UNY Press.

[7] Hill, T.A., (2005). Character First! Kimray Inc., http://www.charactercities.org/ downloads/publications/Whatischar acter.pdf.

[8] Leblanc, Patrice R \& Gallavan, Nancy P. (2009). Affective Teacher Education. New York: Association of Teacher Educattor

[9] Zuchdi, Darmiyati, Prasetya, Zuhdan K., Masruri, dan Muhsinatun S. (2010). "Pengembangan Model Pendidikan Karakter Terintegrasi dalam Pembelajaran Bidang Studi di Sekolah Dasar". Cakrawala Pendidikan XXIX, edisi Dies Natalis UNY: $1-12$

[10] Anderson, L. W., \& Bourke, S. F. (2013). Assessing affective characteristics in the schools. Routledge.

[11] Chen, W.-H. (2013). Applying problem based learning model and creative design to conicsections teaching. International Journal of Education and Information Technologies, 3(7), 73-80.

[12] Rianto, Y. (2010). Paradigma baru pembelajaran. sebagai referensi bagi guru/pendidik dalam implementasi pembelajaran yang efektif dan berkualitas. Jakarta: Kencana Media Group 
[13] Afandi dan Sajidan 2017. Stimulasi Ketrampilam Berpikir Tingkat Tinggi : Konsep dan Implikasi Dalam Pembelajan Abad 21. Surakarta : UPT UNS Press

[14] Widyatiningtyas, R., Kusumah, Y. S., Sumarmo, U., \& Sabandar, J. (2015). The Impact of Problem-Based Learning Approach to Senior High School Students' Mathematics Critical Thinking Ability. Indonesian Mathematical Society Journal on Mathematics Education, 6(2), 30-38.

[15] Wildan, W., Hakim, A., Laksmiwati, D., \& Supriadi, S. (2019). Sosialisasi Perangkat Pembelajaran Berbasis Lingkungan Untuk Guru Ipa Smp/Mts Di Lombok Barat Dalam Upaya Mengurangi Laju Pemanasan Global. Jurnal Pendidikan dan Pengabdian Masyarakat, 2(1).

[16] Amir, M. Taufiq. (2009). Inovasi Pendidikan Melalui Problem Based Learning, Jakarta: Media Group, Cet. 1

[17] Arends, R. I. (2010). Learning toTeach: 9th Edition. NewYork: McGraw-Hill.

[18] Phee, A.D.Mc. (2002). Problem base learning in initial teacher education: taking agenda forward. Journal of education enquiry, 3 (1): 60-74

[19] Akcay, B. (2009). Problem base learning in science education. Journal of Turkish Education, 6 (1): 26-35
[20] Belt, S. T., Evans, E. H., McCreedy, T., Overton, T. L. and Summerfield, S. (2002). A problembased learning approach to analytical and applied chemistry. Univ. Chem. Educ.,6, 65-72.

[21] HmeloSilver, C. E., \& Barrows, H. S. (2006). Goals and strategies of a problem-based learning facilitator. The interdisciplinary Journal of Problembased Learning, 1(1), 21-39.

[22] Echavarria, M. V. (2010). Problem-based learning application in engineering. Revista EIA. scieloco.

[23] Machingambi, S. (2013). Instructional strategies for motivating students: Reflections from 13 years of teaching in higher education. International Journal of Educational Sciences, 5(3), 227-235.

[24] Torrance, E.P \& Khatena, J. (2006). KhatenaTorrance Creative Perception Inventory. Chicago: Stoelting Company.

[25] Nugroho, Widyo Sulasdi (2011). Integrasi Pendidikan Berkarakter Kurikulum MIPA dan Pendidikan MIPA. Seminar Nasional FMIPA UNP. Padang: 19 November 2011.

[26] Martawijaya, M.A. (2015). Karakter Peserta Didik dan Hubungannya Dengan Keterampilan Berpikir Kritis Dalam Pembelajaran Fisika Siswa SMP. Journal of EST, 1 (2): $1-7$ 